\title{
CHEMICAL COMPOSITION, CYTOTOXIC AND ANTIOXIDANT ACTIVITIES OF CELOSIA TRIGYNA L. GROWN IN SAUDI ARABIA
}

\author{
SAMY KORANY EL-DESOUKY ${ }^{1,2 *}$, AHMED AWAD ABDELGAWAD ${ }^{1,3}$, \\ ALI MOHAMED EL-HAGRASSI ${ }^{2}$, USAMA WAHID HAWAS ${ }^{2,4}$ \\ and YOUNG-KYOON KIM ${ }^{5}$
}

\author{
${ }^{1}$ Chemistry Department, Faculty of Science, Jazan University, 2097 Jazan, \\ Kingdom of Saudi Arabia \\ ${ }^{2}$ Phytochemistry and Plant Systematic Department, \\ National Research Centre, Dokki, 12311, Cairo, Egypt \\ ${ }^{3}$ Medicinal and Aromatic Plants Department, Desert Research Center, Cairo, Egypt \\ ${ }^{4}$ Marine Chemistry Department, Faculty of Marine Sciences, \\ King Abdulaziz University, Jeddah 21589, Kingdom of Saudi Arabia \\ ${ }^{5}$ Forest Products Department, College of Forest Science, Kookmin University, \\ 861-1 Chongnung-Dong, Songbuk-Gu, Seoul, 136-702, Korea
}

\begin{abstract}
The methanol extract of the aerial parts of Celosia trigyna (Amaranthaceae) was successively fractionated using $n$-hexane, dichloromethane, ethyl acetate, and $n$-butanol. The cytotoxic activity of the obtained fractions was investigated using sulphorhodamine-B (SRB) assay against three carcinoma cell lines; breast adenocarcinoma (MCF-7), colorectal carcinoma (HCT-116) and hepatocellular carcinoma cells (HepG2). The dichloromethane fraction showed significant in vitro cytotoxic activities against the human cancer cell lines HCT-116 and HEP-G2 with $\mathrm{IC}_{50}$ values of 10.9 and $11.2 \mu \mathrm{g} / \mathrm{mL}$, respectively, while all fractions revealed weak antioxidant activity using DPPH free radical scavenging method. The GC-MS analysis of the most cytotoxic dichloromethane fraction has resulted in the identification of 12 compounds. The main constituents were tetrahydroisoquinoline derivative (31.44\%), 2,3-dimethylheptadecane $(16.71 \%)$ and 3-octadecanone $(15.56 \%)$. Moreover, the phytochemical study of the dichloromethane and $n$-butanol fractions led to the isolation and identification of five known compounds identified as $\beta$-amyrin acetate $(\mathbf{1})$, acacetin $8-C$ - $\alpha$-rhamnosyl- $(1 \rightarrow 2)-\beta$-glucopyranoside (2), apigenin 8 - $C$ - $\alpha$-rhamnosyl-( $1 \rightarrow 2)$ - $\beta$-glucopyranoside (3), quercetin 3-O- $\alpha$-rhamnosyl$(1 \rightarrow 6)$ - $\beta$-glucopyranoside (4) and 3-hydroxyglutaric acid (5).
\end{abstract}

Keywords: Celosia trigyna, cytotoxic activity, antioxidant activity, flavonoid-glycosides, GC-MS

The genus Celosia is a member of edible and ornamental plants of the family Amaranthaceae. It comprises about 65 species distributed in tropical and warm regions of the world $(1,2)$. Two species are grown in Saudi Arabia, including C. trigyna L., and $C$. polystachya Forssk $(3,4)$. Some plants of this genus exhibit pharmacological activities such as antioxidant, antidiabetic, tonic, immune-stimulatory, antitumor, antibacterial, anti-inflammatory, antiosteoporosis, antiulcer, hypolipidemic, diuretic, larvicidal, antihypertensive, hypoglycemic and analgesic activity (5).

C. trigyna is an annual erect herb commonly called silver spinach, distributed in tropical Africa and grows in southwestern mountainous region in Saudi Arabia. The leaves and flowers of C. trigy$n a$ are used for the treatment of diarrhea and excessive menstruation. The fresh leaves are taken for heart complaints and applied locally to boils and skin diseases (6). C. trigyna justify its inclusion in traditional recipes for the treatment of cancer in some studies as it has shown a potential cytotoxic activity (7). Some pharmacological studies revealed that $C$. trigyna has analgesic and antioxidant activity $(8,9)$.

The previous phytochemical investigation of the plants from the genus Celosia have led to the isolation of diverse chemicals, including flavonoids

* Corresponding author: e-mail: desoky5@hotmail.com 
$(10,11)$, terpenoids and saponins (12-16), polysaccharides (17), alkaloids (18), cyclic peptides (19$22)$, palmitic and oleanolic acid $(15,23)$, phenolics (24), and fatty acids (25).

Flavonoid- $O$-glycosides, isoflavonoids and their aglycones also are common in Celosia genus (26-30). However, although C. trigyna is a wellknown plant in the traditional folk medicine of many cultures, it has not been subjected to extensive phytochemical and therapeutic study. Only one phytochemical screening study on the leaves of this plant species showed it contains flavonoids, amino acids, terpenoids, saponins, and anthraquinones (8).

Study of phytochemical composition of some species belonging to the genus Celosia may help in its chemotaxonomic classification in the Flora of Saudi Arabia. The aim of this study is to investigate the phytochemical composition of the methanol extract of $C$. trigyna as well as evaluating the antioxidant activity of the obtained fractions using DPPH free radical scavenging method and the cytotoxic activity against three carcinoma cell lines; breast adenocarcinoma (MCF-7), colorectal carcinoma (HCT-116) and hepatocellular carcinoma cells (HepG2) using sulphorhodamine-B (SRB) assay.

\section{MATERIALS AND METHODS}

\section{Plant material}

The aerial parts of $C$. trigyna L. were collected during the flowering period from Wadi Lejib road and Jabal Fayfa in Jazan region, Saudi Arabia (latitude: 17³5'28.0" N and longitude: 42 $55^{\circ}$ '41.1' E ) in April 2016 and identified by Dr. Wael T. Kassim, Department of Botany, Jazan University, Saudi Arabia. A voucher specimen (120-42016) has been deposited in Jazan University Herbarium (JAZUH).

\section{General experimental methods}

Silica gel $60(0.063-0.200 \mathrm{~mm}$, Merck, Germany), Sephadex LH-20 (Lipophilic Sephadex, 25-100 um, Sigma-Aldrich USA) and Polyamide 6C (Fluca USA) were for column chromatography. Silica gel 60 F254 plates (Merck, Germany) was used for thin-layer chromatography analysis. The chromatograms were visualized under UV light then sprayed with anisaldehyde and vanillin reagents. UV spectra were recorded on an HP Agilent 8453 (USA) Infra-Red spectra were recorded on a Bruker IFS instrument. ESI-MS was performed on Finnigan MAT SSQ 7000 instrument. NMR spectra for the isolated metabolites were obtained on Bruker 400 spectrometers using TMS as an internal standard.

\section{Extraction and isolation}

The air-dried, powdered aerial parts of $C$. trygina $(565 \mathrm{~g})$ were extracted thrice with methanol $(3 \times 2 \mathrm{~L})$ at room temperature $(24 \mathrm{~h}$ each $)$. The combined extract was concentrated under reduced pressure to yield a sticky dark gum (39.7 g). The crude extract was suspended in $500 \mathrm{~mL}$ water and successively partitioned with $n$-hexane, dichloromethane $\left(\mathrm{CH}_{2} \mathrm{Cl}_{2}\right)$, ethyl acetate (EtOAc), and $n$-butanol $(\mathrm{BuOH})$. Each fraction was concentrated in vacuo to yield dry extracts $(25.03 \mathrm{~g}, 3.27 \mathrm{~g}, 4.0 \mathrm{~g}, 7.4 \mathrm{~g})$, respectively. The $\mathrm{CH}_{2} \mathrm{Cl}_{2}$ extract ( $3.72 \mathrm{~g}$ ) was subjected to silica gel open column chromatography (230-400 mesh) and eluted using $n$-hexane-EtOAc mixture with increasing polarity to afford $\mathbf{1 2}$ fractions. Based on thin-layer chromatography (TLC) profiles on silica gel eluted with $n$-hexane/EtOAc (10:1, v/v), fractions 2-7 were combined and further separated using silica gel column chromatography with $n$-hexane/EtOAc (15: 1-5:1, v/v) to afford compound $\mathbf{1}$ (60 mg, white powder). Fractions 8-10 were combined (TLC on silica gel eluted with $n$-hexane/EtOAc $20: 1, \mathrm{v} / \mathrm{v}$ ) then subjected to silica gel column chromatography using the same TLC system to afford compound $\mathbf{5}$ (colorless liquid). The $n$ - $\mathrm{BuOH}$ extract (7.4 g) was separated by polyamide column chromatography eluted with water/ethanol with decreasing polarity to afford 20 fractions. Combined fractions 5-9 (paper chromatography (PC) using the eluent butanol /acetic acid /water, 4 : $1: 5, \mathrm{v} / \mathrm{v}$ ) were separated by preparative PC using the same eluent system and further purified with Sephadex LH-20 column chromatography using $\mathrm{MeOH}$ to give compound 4 (140 mg, yellowish powder). Compound $\mathbf{3}$ (82 $\mathrm{mg}$, yellowish powder) was isolated from the combined fractions 11-15 (preparative PC using the eluent $15 \%$ acetic acid) and purified by Sephadex LH-20 column chromatography eluting with $\mathrm{MeOH}$. Similarly, fractions 17-20 were combined (PC using the eluent system butanol /acetic acid /water, $4: 1: 5$, v/v) then purified on Sephadex LH-20 column chromatography eluted with the isocratic system methanolethanol (1:1) to give compound $2(125 \mathrm{mg})$ as a yellow amorphous powder.

\section{Gas chromatography-mass spectrometry (GC- MS) analysis}

The dichloromethane soluble fraction of C. trygina was analyzed using Thermo Scientific GC-MS equipped with AS 3000 autosampler, trace ultra GC and ISQ detector. A non-polar column consisting of $5 \%$ phenylpolysilphenylene siloxane (Thermo Scientific TR 5MS) with dimensions of $30 \mathrm{~m} \times 0.25$ 
Table $1 .{ }^{13} \mathrm{C}$-NMR $\left(150 \mathrm{MHz}, \mathrm{CDCl}_{3}\right)$ data and selected HMBC correlations of compound 1.

\begin{tabular}{|c|c|c|c|c|}
\hline \multicolumn{5}{|c|}{$\beta$-amyrin acetate } \\
\hline Position & $\delta_{\mathrm{c}}(\mathrm{ppm})$ & Position & $\delta_{\mathrm{c}}(\mathrm{ppm})$ & \\
\hline 1 & 38.26 & 16 & 23.53 & \\
\hline 2 & 26.92 & 17 & 41.70 \\
\hline 3 & 80.94 & 18 & 47.22 & \\
\hline 4 & 36.84 & 19 & 46.78 \\
\hline 5 & 55.25 & 20 & 31.09 \\
\hline 6 & 18.26 & 21 & 37.14 \\
\hline 7 & 34.73 & 22 & 32.58 \\
\hline 8 & 37.71 & 23 & 28.40 \\
\hline 9 & 47.55 & 24 & 16.81 \\
\hline 10 & 32.49 & 25 & 15.56 \\
\hline 11 & 23.57 & 26 & 16.71 \\
\hline 12 & 121.64 & 27 & 28.04 \\
\hline 13 & 145.21 & 28 & 23.70 \\
\hline 14 & 39.80 & 29 & 33.35 \\
\hline 15 & 26.13 & 30 & 25.95 \\
\hline 1 & 171.02 & & \\
\hline 2 & 21.33 & & \\
\hline & & \\
\hline & &
\end{tabular}

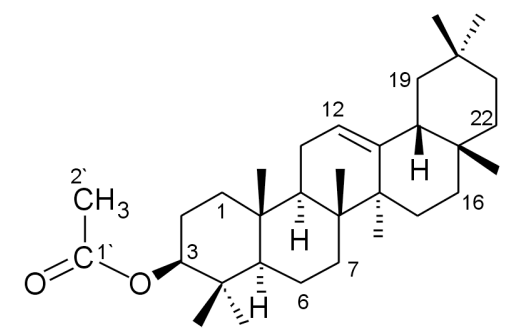<smiles>O=C(O)CC(O)CC(=O)O</smiles><smiles>[R2]c1ccc(-c2cc(=O)c3c(O)cc(O)c(C)c3o2)cc1</smiles>

$2 \mathrm{R}=\mathrm{CH}_{3}$

$3 \mathrm{R}=\mathrm{H}$<smiles>C[C@H]1O[C@H](OC[C@H]2O[C@H](Oc3c(-c4ccc(O)c(O)c4)oc4cc(O)cc(O)c4c3=O)[C@@H](O)[C@H](O)[C@H]2O)[C@H](O)[C@@H](O)[C@@H]1O</smiles>

4

Figure 1. Chemical structures of compounds 1-5 from C. trigyna 
$\mathrm{mm}$ (internal diameter) $\times 0.25 \mu \mathrm{m}$ (film thickness) was used for separation of the components. Helium, at a flow rate of $1 \mathrm{~mL} / \mathrm{min}$ (constant flow mode), was used as a carrier gas. A volume of $2 \mu \mathrm{L}$ of sample extracts was injected in splitless mode. The injection port was set at $260^{\circ} \mathrm{C}$ and the temperature of the was initially set at $50^{\circ} \mathrm{C}$ for $2 \mathrm{~min}$. Then it was ramped to $140^{\circ} \mathrm{C}$ at rate of $5^{\circ} \mathrm{C} / \mathrm{min}$ for $2 \mathrm{~min}$ and finally to $280^{\circ} \mathrm{C}$ at rate of $3^{\circ} \mathrm{C} / \mathrm{min}$ for $50 \mathrm{~min}$. The maximum oven temperature was set at $330^{\circ} \mathrm{C}$. The mass spectrometer was operated in an electron ionization (EI) mode within the mass range of 50-700 amu with 20 scan times (min). The MS transfer line temperature and ion source temperature were kept at $290^{\circ} \mathrm{C}$ and $300^{\circ} \mathrm{C}$ respectively with electron multiplier voltage of $1 \mathrm{Kv}$. The mass spectra were interpreted using the reference library of the National
Institute of Standards and Technology (NIST), US, along with Willey 5 and mass finder, as well as data reported by Adams (31). The constituent percentages were measured based on the peak area. The components were identified after comparison with those available in the computer library (NIST and Willey) attached to the GC-MS instrument.

\section{Cell culture and in vitro cytotoxic activity}

Three human tumor cell lines, breast adenocarcinoma (MCF-7), colorectal carcinoma (HCT-116) and hepatocellular carcinoma cells (HepG2) were used in this study and obtained from the American Type Culture Collection, Minnesota, USA. The cell lines were maintained at the National Cancer Institute, Cairo, Egypt, by serial subculturing. The samples were prepared by dissolving 1: 1 stock

Table 2. Cytotoxic activity of dichloromethane, ethyl acetate, n-butanol and $n$-hexane fractions of C. trigyna.

\begin{tabular}{|c|c|c|c|c|c|c|}
\hline \multirow{2}{*}{ Conc. $(\mu \mathrm{g} / \mathrm{mL})$} & \multicolumn{3}{|c|}{ Dichloromethane } & \multicolumn{3}{|c|}{ Ethyl acetate } \\
\hline & MCF7 & HCT-116 & HEPG2 & MCF7 & HCT-116 & HEPG2 \\
\hline 0 & 1 & 1 & 1 & 1 & 1 & 1 \\
\hline 12.5 & 0.903 & 0.439 & 0.435 & 0.956 & 0.964 & 0.91 \\
\hline 25 & 0.741 & 0.431 & 0.385 & 0.792 & 0.906 & 0.75 \\
\hline 50 & 0.534 & 0.513 & 0.335 & 0.414 & 0.846 & 0.54 \\
\hline 100 & 0.395 & 0.581 & 0.33 & 0.352 & 0.821 & 0.55 \\
\hline $\mathrm{IC}_{50}$ & 62.7 & 10.9 & 11.2 & 44.4 & n.d.* & n.d. \\
\hline \multirow{2}{*}{ Conc. $(\mu \mathrm{g} / \mathrm{mL})$} & \multicolumn{3}{|c|}{ n-Butanol } & \multicolumn{3}{|c|}{$n$-Hexane } \\
\hline & MCF7 & HCT-116 & HEPG2 & MCF7 & HCT-116 & HEPG2 \\
\hline 0 & 1 & 1 & 1 & 1 & 1 & 1 \\
\hline 12.5 & 0.973 & 0.940 & 0.885 & 0.880 & 0.812 & 0.760 \\
\hline 25 & 0.871 & 0.666 & 0.795 & 0.703 & 0.870 & 0.695 \\
\hline 50 & 0.664 & 1.041 & 0.640 & 0.403 & 0.949 & 0.665 \\
\hline 100 & 0.385 & 1.051 & 0.550 & 0.282 & 0.940 & 0.580 \\
\hline $\mathrm{IC}_{50}$ & 78.7 & n.d. & n.d. & 42.1 & n.d. & n.d. \\
\hline
\end{tabular}

*n.d. (not determined)

Table 3. Antioxidant activity of dichloromethane, ethyl acetate, $n$-butanol and n-hexane fractions of $C$. trigyna.

\begin{tabular}{|l|c|c|c|}
\hline \multicolumn{1}{|c|}{ Sample } & $\mathrm{IC}_{50}(\mu \mathrm{g} / \mathrm{mL})$ & $\mathrm{LC}_{90}(\mu \mathrm{g} / \mathrm{mL})^{*}$ & Remarks \\
\hline$n$-Hexane fraction & 207.0 & 345.0 & $11.4 \%$ at $100 \mu \mathrm{g} / \mathrm{mL}$ \\
\hline Dichloromethane fraction & 129.6 & 208.7 & $25.5 \%$ at $100 \mu \mathrm{g} / \mathrm{mL}$ \\
\hline Ethyl acetate fraction & 164.4 & 256.0 & $14.3 \%$ at $100 \mu \mathrm{g} / \mathrm{mL}$ \\
\hline$n$-Butanol fraction & n.d. ${ }^{*}$ & n.d.* & $10.1 \%$ at $100 \mu \mathrm{g} / \mathrm{mL}$ \\
\hline
\end{tabular}

$* \mathrm{The} \mathrm{IC}_{50}$ value of the positive control, butylated hydroxyanisole (BHA), was measured as $53 \pm 3.1 \mu \mathrm{g} / \mathrm{mL}$. $*$ The $\mathrm{IC}_{90}$ value of the positive control, vitamin C, was measured as $12 \pm 3.5 \mu \mathrm{g} / \mathrm{mL}$. *n.d. (not determined) 


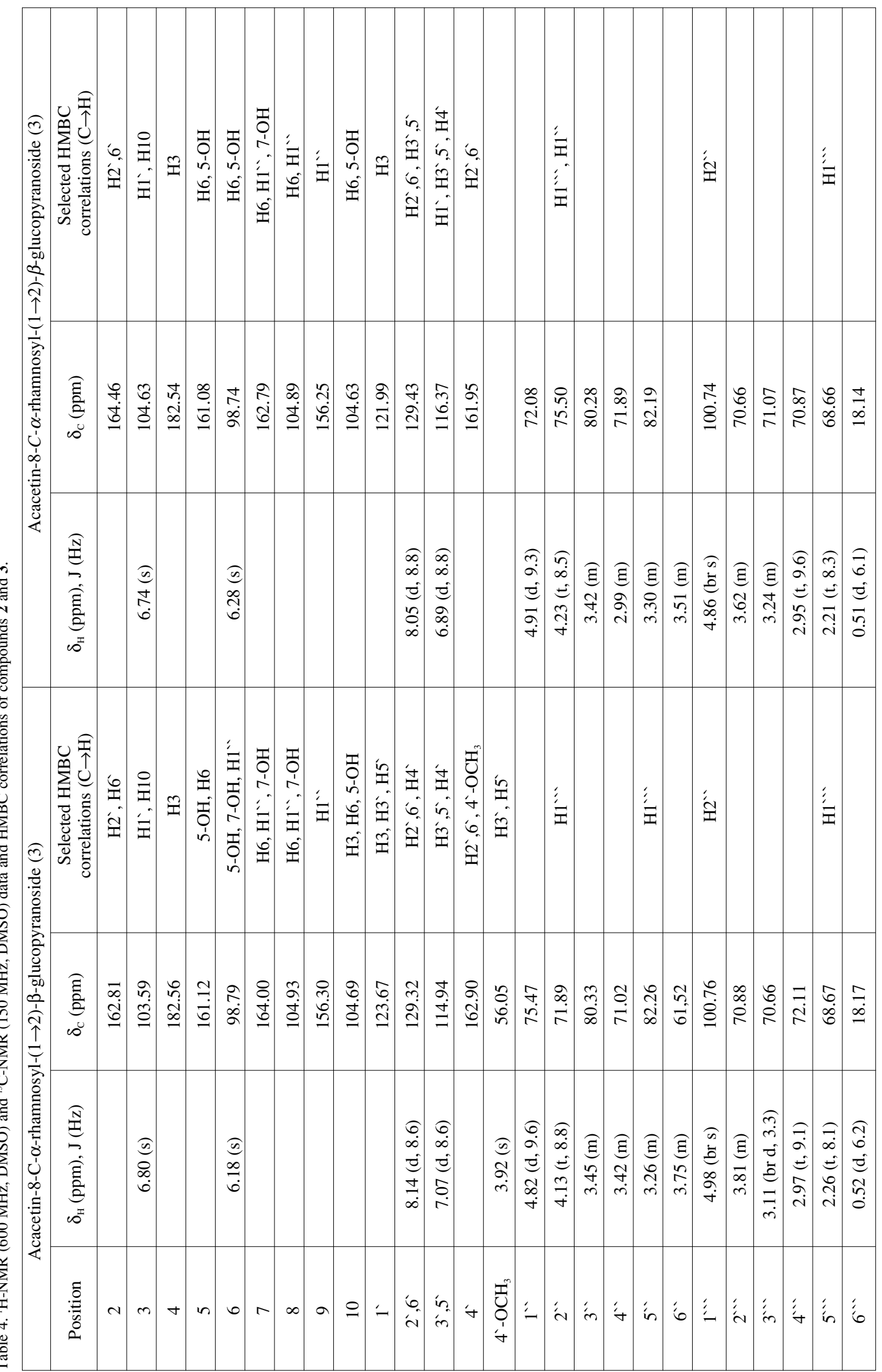


solution in dimethylsulfoxide at $100 \mathrm{mmol} / \mathrm{L}$ and stored at $-20^{\circ} \mathrm{C}$.

The cytotoxicity of the obtained fractions was carried out using sulphorhodamine-B (SRB) assay following the method reported by Vichai (32). The cytotoxicity of the samples was compared with doxorubicin, the control anticancer drug. SRB is a bright pink aminoxanthrene dye with two sulphonic groups. It is a protein stain that binds to the amino groups of intracellular proteins under mildly acidic conditions to provide a sensitive index of cellular protein content. The cells were seeded in 96-well microtiter plates at initial concentration of $3 \times 10^{3}$ cell/well in a $150 \mu \mathrm{L}$ fresh medium and left for $24 \mathrm{~h}$ to attach to the plates. Different concentrations 0,5, $12.5,25,50 \mu \mathrm{g} / \mathrm{mL}$ of extracts were added. The fractions at each concentration were tested in triplicate. The cells were treated with different fractions for 48 hours. Next, the cells were fixed with $50 \mu \mathrm{L}$ cold trichloroacetic acid $10 \%$ final concentration for 1 hour at $4^{\circ} \mathrm{C}$. The plates were washed with distilled water using (automatic washer Tecan, Germany) and stained with $50 \mu \mathrm{L} 0.4 \%$ SRB dissolved in $1 \%$ acetic acid for $30 \mathrm{~min}$ at room temperature then washed with $1 \%$ acetic acid and air-dried.

The dye was solubilized with $100 \mu \mathrm{L} /$ well of $10 \mathrm{M}$ Tris base (pH 10.5) and optical density (O.D.) of each well was measured spectrophotometrically at $570 \mathrm{~nm}$ with a microplate reader (Sunrise Tecan reader, Germany). The mean background absorbances were automatically subtracted and mean values of each extract concentration was calculated.

The percentage of cell survival was calculated as follows:

Surviving fraction $=$ O.D. $($ treated cells $) /$

O.D. (control cells).

The $\mathrm{IC}_{50}$ values (the concentrations of drug required to produce $50 \%$ inhibition of cell growth) were also calculated.

\section{Free radical scavenging activity}

The free radical scavenging activity of extracts was measured by 1,1-diphenyl-2-picryl-hydrazil (DPPH) using the Shimada method (33). All

Table 5. ${ }^{1} \mathrm{H}-\mathrm{NMR}(600 \mathrm{MHz}, \mathrm{MeOD})$ and ${ }^{13} \mathrm{C}-\mathrm{NMR}(150 \mathrm{MHz}, \mathrm{MeOD})$ data and HMBC correlations of compound 4.

\begin{tabular}{|c|c|c|c|}
\hline \multicolumn{4}{|c|}{ Quercetin -3- $O$ - $\alpha$ - rhamnosyl-( $1 \rightarrow 6)-\beta$-glucopyranoside (4) } \\
\hline Position & $\delta_{\mathrm{H}}(\mathrm{ppm}), \mathrm{J}(\mathrm{Hz})$ & $\delta_{\mathrm{C}}(\mathrm{ppm})$ & $\begin{array}{c}\text { Selected HMBC } \\
\text { correlations }(\mathrm{C} \rightarrow \mathrm{H})\end{array}$ \\
\hline 2 & & 157.45 & $\mathrm{H} 2{ }^{\prime}, \mathrm{H} 6$ \\
\hline 3 & & 134.47 & $\mathrm{H} 1{ }^{\prime \prime}$ \\
\hline 4 & & 177.87 & \\
\hline 5 & & 161.30 & H6 \\
\hline 6 & $6.16(\mathrm{~d}, 2.1)$ & 98.74 & H8 \\
\hline 7 & & 164.90 & $\mathrm{H6}$, H8 \\
\hline 8 & $6.34(\mathrm{~d}, 2.1)$ & 93.63 & H6 \\
\hline 9 & & 156.91 & $\mathrm{H} 8$ \\
\hline 10 & & 104.63 & $\mathrm{H} 6, \mathrm{H} 8$ \\
\hline 1 & & 121.72 & $\mathrm{H} 2$ \\
\hline 2 & $7.87(\mathrm{~d}, 2.3)$ & 114.75 & \\
\hline 3 & & 144.23 & $\mathrm{H} 2^{\prime}, \mathrm{H} 5$ \\
\hline 4 & & 148.54 & $\mathrm{H} 2{ }^{\prime}, \mathrm{H} 5, \mathrm{H} 6$ \\
\hline 5 & $6.87(\mathrm{~d}, 8.6)$ & 116.66 & H6 \\
\hline 6 & $7.57(\mathrm{dd}, 8.6,2.3)$ & 121.36 & H5 \\
\hline $1 "$ & $5.12(\mathrm{~d}, 8.1)$ & 104.01 & \\
\hline $\begin{array}{l}2 “, 3^{\prime \prime}, 4^{\prime \prime}, 5^{\prime \prime}, 2^{\cdots}, \\
3 \cdots, 4^{\cdots}, 5^{\cdots}\end{array}$ & $3.31-3.86(\mathrm{~m}, 8 \mathrm{H})$ & $\begin{array}{l}71.77,73.67,68.80,73,80 \\
70.88,70.61,72.49,68.31\end{array}$ & \\
\hline $6^{\prime \prime}$ & $\begin{array}{l}3.63(\mathrm{~m}) \\
3.68(\mathrm{~m})\end{array}$ & 65.98 & $\mathrm{H} 1^{\cdots}$ \\
\hline $1 \cdots$ & 4.54 (br s) & 101.01 & \\
\hline $6^{\prime \prime}$ & $1.23(\mathrm{~d}, 6.1)$ & 16.61 & \\
\hline
\end{tabular}


Table 6. Chemical composition of the dichloromethane soluble fraction of the aerial parts of $C$. trigyna.

\begin{tabular}{|c|c|c|c|c|c|}
\hline No & Compound & RT & Probability & Molecular Formula & Percentage $\%$ \\
\hline 1 & tert-Hexadecanethiol & 20.37 & 12.29 & $\mathrm{C}_{16} \mathrm{H}_{34} \mathrm{~S}$ & 1.31 \\
\hline 2 & 1-Hexadecanol & 27.71 & 4.2 & $\mathrm{C}_{16} \mathrm{H}_{34} \mathrm{O}$ & 2.58 \\
\hline 3 & 2,6,10-Trimethyltetradecane & 31.71 & 18.26 & $\mathrm{C}_{17} \mathrm{H}_{36}$ & 1.97 \\
\hline 4 & 3-Heptadecanone & 37.71 & 61.45 & $\mathrm{C}_{17} \mathrm{H}_{34} \mathrm{O}$ & 6.5 \\
\hline 5 & 3-Octadecanone & 44.04 & 17.89 & $\mathrm{C}_{18} \mathrm{H}_{36} \mathrm{O}$ & 15.56 \\
\hline 6 & Tetracosane, 11-decyl- & 50.38 & 7.54 & $\mathrm{C}_{34} \mathrm{H}_{7} \mathrm{O}$ & 3.73 \\
\hline 7 & 3-Chloropropionic acid, heptadecyl ester & 57.38 & 10.85 & $\mathrm{C}_{20} \mathrm{H}_{39} \mathrm{ClO}_{2}$ & 7.55 \\
\hline 8 & $\begin{array}{l}\text { 1,2,3,4-Tetrahydroisoquinoline, 1-[phenyl } \\
\text { (hydroxymethyl)]-6,7-dim ethoxy-2-methyl }\end{array}$ & 65.38 & 62.18 & $\mathrm{C}_{19} \mathrm{H}_{23} \mathrm{NO}_{3}$ & 31.44 \\
\hline 9 & Heptadecane, 2,3-dimethyl- & 72.05 & 5.11 & $\mathrm{C}_{19} \mathrm{H}_{40}$ & 16.71 \\
\hline 10 & 7,8-Epoxylanostan-11-ol, 3-acetoxy & 81.72 & 19.17 & $\mathrm{C}_{32} \mathrm{H}_{54} \mathrm{O}_{4}$ & 3.22 \\
\hline 11 & Oleic acid, 3-(octadecyloxy) propyl ester & 89.39 & 7.97 & $\mathrm{C}_{39} \mathrm{H}_{76} \mathrm{O}_{3}$ & 0.34 \\
\hline 12 & $\begin{array}{l}\text { 7,9-Di-tert-butyl-1-oxaspiro(4,5)deca-6,9- } \\
\text { diene-2,8-dione }\end{array}$ & 93.056 & 9.89 & $\mathrm{C}_{17} \mathrm{H}_{24} \mathrm{O}_{3}$ & 9.04 \\
\hline \multicolumn{5}{|c|}{ Total \% } & $99.96 \%$ \\
\hline
\end{tabular}

extracts were screened at $100 \mu \mathrm{g} / \mathrm{mL}$ while the most potent active extracts (gave more 90\%) were assayed at $25-75 \mu \mathrm{g} / \mathrm{mL}$. Briefly, $0.1 \mathrm{mM}$ solution of DPPH in methanol was prepared. Then, $1 \mathrm{~mL}$ of this solution was added to $3 \mathrm{~mL}$ of extract solution at different conc. $(25-75 \mu \mathrm{g} / \mathrm{mL})$. The mixture was shaken vigorously and allowed to stand at room temperature for $30 \mathrm{~min}$. Then the absorbance was measured at $517 \mathrm{~nm}$ in a microplate reader. Lower absorbance of the reaction mixture indicated higher free radical scavenging activity.

$$
\begin{gathered}
\text { DPPH scavenging effect }(\%)= \\
100-\left[\left(\left(\mathrm{A}_{0}-\mathrm{A}_{1}\right) / \mathrm{A}_{0}\right) \times 100\right]
\end{gathered}
$$

where $A_{0}$ was the absorbance of the control reaction and $A_{1}$ was the absorbance in the presence of the sample (34).

\section{RESULTS AND DISCUSSION}

\section{Structure elucidation}

The main reason to focus some light on $C$. trig$y n a$ is the widespread ethnomedical uses and the lack of phytochemical studies of this plant species in Arab peninsula (6-9).

The present study describes the isolation and identification of five compounds from the aerial parts of this plant (Fig. 1) including one oleananetype pentacyclic triterpenes $\mathbf{1}$; two flavonoid- $C$-glycosides, 2-3, one flavonoid- $O$-glycoside 4 and 3hydroxyglutaric acid 5. This is the first report of compounds 1-5 from the species $C$. trigyna.
Moreover, compound $\mathbf{5}$ has not been isolated previously from Amaranthaceae.

The structures of the obtained compounds were elucidated by interpretation of their spectral data, including 1D- and 2D-NMR $\left({ }^{1} \mathrm{H},{ }^{13} \mathrm{C}\right.$, DEPT-135, HSQC, and HMBC) (Tables 1, 4 and 5) and by comparison with those reported data in the related literature (35-39). The compounds were identified as $\beta$ amyrin acetate (1), acacetin-8- $C$ - $\alpha$-rhamnosyl$(1 \rightarrow 2)$ - $\beta$-glucopyranoside (2), apigenin- $8-C$ - $\alpha$ rhamnosyl-( $1 \rightarrow 2)$ - $\beta$-glucopyranoside (3), quercetin3 - $O$ - $\alpha$-rhamnosyl-( $1 \rightarrow 6)$ - $\beta$-glucopyranoside $(4)$ and 3-hydroxyglutaric acid (5).

\section{In vitro cytotoxicity and antioxidant activity}

The cytotoxic effect of the $C$. trigyna organic fractions against different human solid tumor cell lines of breast adenocarcinoma (MCF-7), colorectal carcinoma (HCT-116) and hepatocellular carcinoma cells (HepG2) was determined. As shown in Table 2, the assay revealing metabolic cytotoxicity of the tested fractions with $\mathrm{IC}_{50}$ ranged from 10.9 to $78.7 \mu \mathrm{g} / \mathrm{mL}$. The dichloromethane fraction showed the highest in vitro cytotoxic effect against HCT116 and HepG2 cells with $\mathrm{IC}_{50}$ values of 10.9 and $11.2 \mu \mathrm{g} / \mathrm{mL}$, respectively, compared to the drug reference doxorubicin. While the MCF7 cells were moderately resistance to the dichloromethane fraction with $\mathrm{IC}_{50}$ values $62.7 \mu \mathrm{g} / \mathrm{mL}$. On the other hand, the ethyl acetate and $n$-hexane fractions exhibited mild activity against the breast carcinoma 
cell lines (MCF7) with $\mathrm{IC}_{50}$ values of 44.4 and 42.1 $\mu \mathrm{g} / \mathrm{mL}$, respectively, and very weak activity against colon and liver carcinoma cell lines at all studied concentrations.

The $n$-hexane, dichloromethane and ethyl acetate fractions exhibited weak antioxidant activities using the DPPH free radical scavenging assay with $\mathrm{IC}_{50}$ values of $207.0 \mu \mathrm{g} / \mathrm{mL}, 129.6 \mu \mathrm{g} / \mathrm{mL}$, $164.4 \mu \mathrm{g} / \mathrm{mL}$, respectively, while $n$-butanol fraction showed very weak antioxidant activity (Table 3 ).

The remarked difference in cytotoxic activities of dichloromethane fraction may be due to the oleanane-type pentacyclic triterpenes content of this fraction. These results are in agreement with the recent findings of Sultana (40) and Fabiyi (41), where they proposed that oleanolic acid and $\beta$ amyrin acetate are powerful cytotoxic metabolites. Further phytochemical and biological studies for this plant species are needed.

\section{GC-MS analysis}

The GC-MS analysis of the dichloromethane soluble fraction of the aerial parts of $C$. trigyna led to the identification and quantification of 12 major components accounting for $99.96 \%$ of the total components present (Table 6). Tetrahydroisoquinoline derivative $(31.44 \%)$, 2,3-dimethylheptadecane (16.71\%), 3-octadecanone (15.56\%), deca-6,9diene-2,8-dione derivative $(9.04 \%)$, and 3 -chloropropionic acid, heptadecyl ester $(7.55 \%)$ were the main components of the extract.

\section{CONCLUSION}

The main purpose of this study was to evaluate the anti-proliferative properties of $C$. trigyna. To our knowledge, this work is likely the first phytochemical study to assess the cytotoxic and antioxidant activities of this plant species. Hence, we can come to the conclusion that the dichloromethane extract demonstrated the highest cytotoxicity against the selected human cancer cell lines MCF-7, HCT-116 and HepG2. The GC-MS analysis of this extract led to the identification and quantification of 12 major compounds belong to 7 classes of compounds including hydrocarbons, alcohols, ketones, esters of fatty acids, steroids, alkaloids, and thiol. Moreover, the phytochemical study of the dichloromethane and $n$-butanol extracts afforded five identified compounds not reported previously for this species. Till date, the presence of novel secondary metabolites with anti-cancer property to justify the inclusion of this plant species in traditional recipes for the treatment of cancer is not reported. Hence, based on the results of our analysis and the low $\mathrm{IC}_{50}$ values of the obtained fractions, further investigation in order to more detailed characterization of chemical composition is still needed.

\section{Acknowledgments}

The authors gratefully acknowledge the financial support for this study from the Deanship of Scientific Research at Jazan University, (Grant No. 37/7/00082). The research also has been partially supported by R\&D Program for Forest Service Technology (Project No. 2017095B10-1919-AB01) provided by the Korea Forest Service (Korea Forestry Promotion Institute).

\section{REFERENCES}

1. Zhang S.M., Wang X.F., Feng, J., Sun Z.L.: Chem. Nat. Compd. 52, 827 (2016).

2. Rajesh P., Rajesh V.K.: Nat. Prod. Res. Rev. 3, 95 (2015).

3. Alfarhan A.H., Al-Turki T.A., Basahy A.Y.: Flora of Jazan Region. King Abdulaziz City for Science and Technology, Ryiadh 2005.

4. Masrahi Y.S., Remesh M., Sayed O.H.: Ecology, Environment and Conservation 23, 99 (2017).

5. Varadharaj V., Muniyappan J.: IJPPR 9, 820 (2017).

6. Rahman M.A, Mossa J.S., Al-Said M.S., AlYahya M.A.: Fitoterapia 75, 149 (2004).

7. Sowemimo A., Van de Venter M., Baatjies L., Koekemoer T.: Afr. J. Trad. Complement Altern. Med. 6, 526 (2009).

8. Makambila-Koubemba M., Mbatchi B., Ardid D., Gelot A., Henrion C. et al.: Int. J. Pharmacol. 7, 608 (2011).

9. Oloyede F.M., Oloyede F.A., Obuotor E.M., Ibironke S.I.: Nigerian J. Nutr. Sci. 32, 13 (2011).

10. Weng D.B., Guan D., Xu Y.J., Wang Q.: Acta Nutrimenta Sinica 17, 59 (1995).

11. Weng D.B., Wang H.F., Weng J.Y.: Chin. Bull. Bot. 17, 565 (2000).

12. Xue Q., Sun Z.L., Guo M.L., Zhang G., Wang Y.: Nat. Prod. Res. 25, 772 (2011).

13. Wu Q.B., Wang Y., Guo M.: Chem. Pharm. Bull. 59, 666 (2011).

14. Wu Q.B., Wang Y., Liang L., Jiang Q., Guo M.L., Zhang J.J.: Nat. Prod. Res. 27, 1353 (2013).

15. Xue Q., Guo M., Zhang G.: Pharm. Care Res. 6, 345 (2006). 
16. Zhang H.C., Zhang T.T., Du B., Cheng D.Y., Li Z.G.: Chinese Trad. Patent Med. 36, 122 (2014).

17. Sun Z., Peng Y., Zhao W.W., Xiao L.L., Yang P.M.: Carbohydr. Polym. 133, 337 (2015).

18. Schliemann W., Cai Y.Z., Degencolb T., Schmidt J., Corke H.: Phytochemistry 58, 159 (2001).

19. Kobayashi J., Suzuki H., Shimbo K., Takeya K., Morita H.: J. Org. Chem. 66, 6626 (2001).

20. Morita H., Suzuki H., Kobayashi J.: J. Nat. Prod. 67, 1628 (2004).

21. Suzuki H., Morita H., Shiro M., Kobayashi J.: Tetrahedron 60, 2489 (2004).

22. Suzuki H., Morita H., Iwasaki S., Kobayashi J.: Tetrahedron 59, 5307 (2003).

23. Fu H.Z., Meng X.Y., Li S.S., Wu L.J.: Chinese Tradit. Herbal Drugs 23, 344 (1992).

24. Molehin O.R., Adefegha S.A., Oboh G., Saliu J.A., Athayde M.L, Boligon A.A.: J. Food Biochem. 38, 575 (2014).

25. Zheng Q.H., Cui X., Zhou P., Li S.L.: J. Chinese Med. Mat. 18, 466 (1995).

26. Vetrichelvan T., Jegadeesan M., Devi B.A.: Biol. Pharm. Bull. 25, 526 (2002).

27. Shuo S., Xiao D., Ming-An O., Zu-Jian W., Lian-Hui X.: J. Asian Nat. Prod. Res. 12, 821 (2010).

28. Cai Y., Sun M., Corke H.: J. Agric. Food Chem. 51, 2288 (2003).
29. Selim S.A. Adam M.E., Hassan S.M., Albalawi A.R.: BMC Complement. Altern. Med. 14, 179 (2014).

30. Aiyegroro O.A., Okoh A.L.: BMC Complement. Altern. Med.10, 21 (2001).

31. Adams R.P.: Identification of essential oil components by gas chromatography/mass spectrometry. $4^{\text {th }}$ ed. Allured Publishing Corporation 2007.

32. Vichai V., Kirtikara K.: Nat Protoc. 1, 1112 (2006).

33. Shimada K., Fujikawa K., Yahara K., Nakamura T.: J. Agric. Food Chem. 40, 945 (1992).

34. Oktay M. Gülçin I., Küfrevioðlu O.: LWT-Food Sci. Technol. 36, 263 (2003).

35. Yang H.P., Que S., Shi Y.P., Ban L.T.: J. Chem. Pharm. Res. 6, 1986 (2014).

36. Jr V.D.E., Shen C.C., Ragasa C.Y.: J. Appl. Pharm. Sci. 5, 33 (2015).

37. Ge Y.B.: Zhong Yao Cai 37, 435 (2014).

38. De Oliveira D.M., Siqueira E.P. Nunes Y.R.F., Cota B.B.: Braz. J. Pharmacogn. 23, 614 (2013).

39. Liang D., Liu Y., Hao Z., Zhang Q., Chen R., Yu D.: Chin. J. Chem. 30, 1269 (2012).

40. Sultana N., Ata A.: J. Enzyme Inhib. Med. Chem. 23, 739 (2008).

41. Fabiyi O.A., Atolani O., Adeyemi O.S. Olatunji G.A.: Asian Pac. J. Trop. Biomed. 2, 981 (2012).

Received: 13.01.2019 